\title{
スポンジケーキの品質におよぼすタンパク質の影響
}

\author{
渡辺雄二*・富田勉**・青木宏*
}

\section{Effect of Proteins on Quality of Sponge Cakes}

\author{
Yuji Watanabe*, Tsutomu Tomita**, Hiroshi Aoki* \\ * Dept. of Food Science and Nutrition, Otsuma Women's Univ., \\ 12 Sanban-cho, Chiyoda-ku, Tokyo, 102 \\ ${ }^{* *}$ Soken-sha Corp., 724 Katakura-machi, Kanagawa-ku, \\ Yokohama-shi, Kanagawa, 221
}

Effect of the addition of egg white (EW), egg albumin (EA) and soy protein isolate (SPI) on quality of sponge cakes was studied in relation to their concentration. With the increase of protein concentration, air content of batter decreased and viscosity increased in all cases. This tendency was more remarkable in SPI than in EW or EA. Specific volume of the SPI-cakes decreased progressively with increasing protein concentration, while that of EW-or EA-cakes had the maximum value at $7.5 \%$ of protein concentration. Through factor analysis, it was suggested that the correlation between attribute in sensory and instrumental evaluation of the EW-cakes was one-dimentional and texture of the cakes was perceived as a relatively simple system. On the contrary, that of the EA-and SPI-cakes was two-dimentional and texture of the cakes was perceived as a complex system.

(Received Mar. 22, 1986)

スポンジヶーキの原料中に含まれるタンパク質の起泡 性と熱疑固性は，ヶーキの体皘を大きく左右する. ${ }^{12)}$ す なわち，ヶーキの膨化作用には，卵白が抱き込んだ空気 の熱膨張が関与し，タンパク質の起泡性が低いと、バッ ター中の空気含量が少なくケーキの膨化作用は抑えられ る. また，膨化作用が行われてあ，熱数固による骨格形 成が不完全な場合には，いわゆる“かまおち”の現象に よって,ケーキの体皘は著しく低下する.

スポンジケーキの品質に関する研究は多く，たとえば ケーキの品質におよぼす原料とその配合比の影㬐, ${ }^{3) 凶}$ 製 造方法の影謷, ${ }^{516)}$ まだッッターおよびケーキの性状変化 とそれら相互の関(系)-9) 等, 多数の研究がなされている. しかし，ヶーキの品質と原料に含まれるタンパク質の機 能特性との関係を論じた研究は，数少ない，その中で， JoHNSON らは卵白に含まれるタンパク質を 6 画分に分 画し，それらの画分の機能特性とヶーキの性状との関係
を明らかにしている。兄しかし，卵白以外の食品汇来 するタンパク質の機能特性との比較は，行われていない。 また，スポンジヶーキ製造の原料として卵白が最通であ ることは，経験的によく知られているが，ての事寒を稟 付ける基礎的な資料は意外佂少ない。

そこで，本研究では卵白，卵アルブミンおよひ大豆分 離タンパク質を用いて、バッターおよびヶーキを調製し， それらのタンパク質濃度を変化させた場合のバッターの 性状とケーキの性状之の関係を比较検討した。なおケ 一キの感覚評価と機器測定値との関係も併せて検討した。

\section{実 験 方 法}

\section{1. 試料}

鶏卵は，実験日 2.日前に産卵したものを東京裑卵株式 会社から賤入し, 冷蔵庫内 (約 $4^{\circ} \mathrm{C}$ ) で 24 時間保藏し たあのを実験に供した。

\footnotetext{
* 大妻女子大学家政学部食物学科 ( $\bar{T} 102$ 東京都千代田区三番町 12 )

** 株式会社創健社（广 221 神奈川県撗浜市神奈川区片倉町 724）
} 
砂螗は，大日本製糖株式会社製，ばら印グラニュー糖 を，小麦粉は，日本製粉株式会社製，八ート印薄力小麦 㸮を使用した。

卵アルブンン（EA）は，和光純菒工業株式会社製， 化学用アルブミン (卵製) を使用した。なお、タンパク 質含量 $(\mathrm{N} \times 6.25)$ は, $87.5 \%$ であった。

大豆分離タンパク質 (SPI) は，未変性脱脂大豆から 常法 ${ }^{10)}$ により酸沈殿タンパク質を調製し，てれを東 結乾嬠したすのを実験に供した。乾燥タンパク質のタン パク質含量 $(\mathrm{N} \times 6.25)$ は，85 88\% であった.

\section{2. タンパク梊容淮の調製法}

EA と SPI のタンパク質溶液は，2.5\%，5.0\%，7.5 \%, 10.0\%，12.5\%，15.0\%の各濃度に調製した。溶 液の最終重量が $150 \mathrm{~g}$ になるように，各濃度に対する 所定量の EA および SPI の粉未を溶解させた。なお， SPI の溶液については，その $\mathrm{pH}$ を 7.0 に $0.2 \mathrm{~N}$ の水 酸化ナトリウム溶液で調整した。

卵白（EW）の場合は，蒸留水を用いて希釈し，2.5 \%, 5.0\%，7.5\%，10.0\% の各濃度に調製した。なお， 希积した液の $\mathrm{pH}$ は，8.11士0.20であった。

\section{3. ケーキの調慗法}

原料の配合は、卵 $150 \mathrm{~g}$ (卵白 $100 \mathrm{~g}$, 卵黄 $50 \mathrm{~g}$ ), 砂糖 $150 \mathrm{~g}$ ，小麦粉 $150 \mathrm{~g}$ とし，Fig. 1 亿示した方法で ケーキを調製した．擋拌機は，万能調理ミキサー（愛工 舎製作所（株）製 A-907 D 型，埼玉）を用いた。調製 したバッター $30 \mathrm{~g}$ をステンレス製の円形カップヶーキ 用の型（底面皘 $22.8 \mathrm{~cm}^{2}$, 上面皘 $42.9 \mathrm{~cm}^{2}$, 高さ 3.2 $\mathrm{cm})$ k入れ，電子式オーブン（松下電器産業(株)製 $\mathrm{NB}-6603$ ，大阪）を用いて $160 \pm 2^{\circ} \mathrm{C}$ で焼成した。㜔成後， 速やかに型抜きをして，室温で 1 時間放冷させたのち， 乾燥させないように包装して，24 時間室温で放置した。 なお，各試験区 1 回につき 9 個のケーキを調製し，同一 試験区につき 6 回絽返した。従って計 54 個のケーキを 調製し、機器測定と感覚評価にそれぞれ 27 個ずつ供し た.

\section{4. ハッターの性状测定}

空気含量 : ステンレス製容器 (底面積 $15.2 \mathrm{~cm}^{2}$, 高 さ $3.3 \mathrm{~cm}$, 容量 $78.0 \mathrm{ml}$ ) でバッターおよび水の重量 を测定し、見掕けの比重を求め， 1 から見猢けの比重を 差し引いたすのをバッターの空気含量とした。

粘度：直径 $5.5 \mathrm{~cm}$ ，高さ $10.5 \mathrm{~cm}$ のガラス製容器 に、バッターを高さ $8 \mathrm{~cm}$ まで入れ，ELD 型粘度計 （東京計器株式会社製，東京)でパッターの粘度を測定 した.

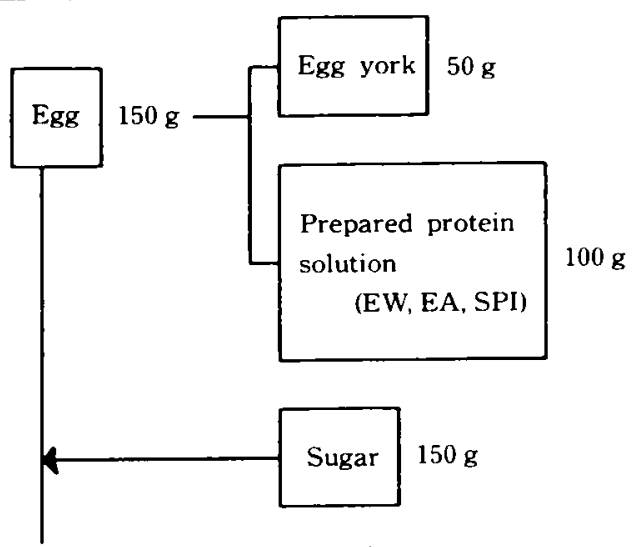

Foamed at $875 \mathrm{rpm}$ for $9 \mathrm{~min}$

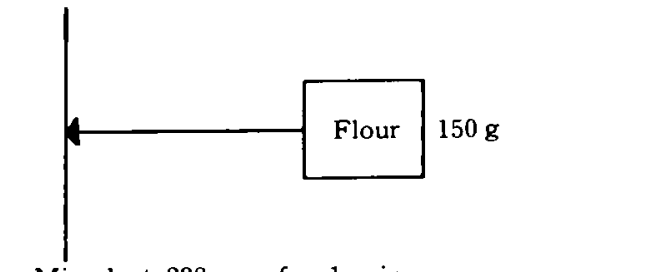

Mixed at $228 \mathrm{rpm}$ for $1 \mathrm{~min}$

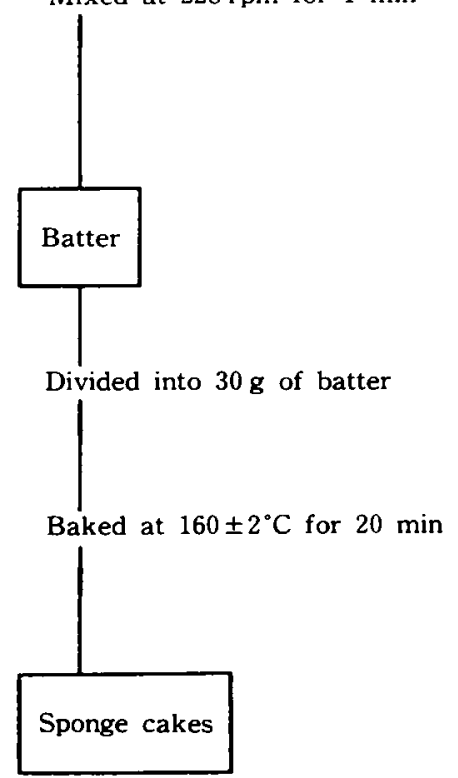

Fig. 1 Flowchart showing preparation of sponge cakes

EW : Egg white, EA : Egg albumin, SPI : Soy protein isolate

5. ケーキの性状测定

気孔率：体積を菜種法で測定しバッターの重量に対 する百分率で表わした。

機器測定：ケーキの中心部から武料を $2 \times 2 \times 2 \mathrm{~cm} の$ 大きさに切断して，レオナー RE-3305 (山電 (株) 製, 
東京）で测定した，硬さ，凝集性，ガム性の測定条件は， 下記のとおりである。

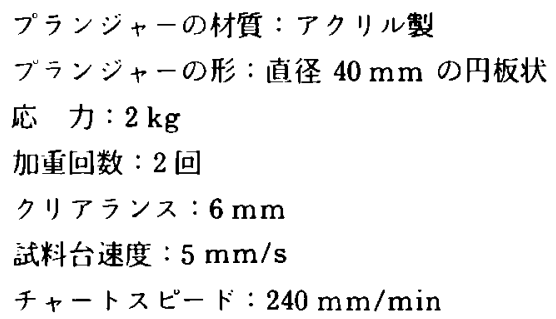

破断強度の測定条件は，次のとおりである。

プランジャーの形：直径 $5 \mathrm{~mm}$ の円筒形

加重回数 : 1 回

クリアランス: $1 \mathrm{~mm}$

試料台速度: $1 \mathrm{~mm} / \mathrm{s}$

なおプランジャーの材質，応力，チャートスビードに ついては，硬さ，凝集性，ガム性の場合と闹樣である。 得られた破断曲線から，破断をしたよきの加重量 $(F)$ を読み取り，下記の式より破断強度を求めた。

破断强度 $\left(\right.$ dyne $\left./ \mathrm{cm}^{2}\right)=F \times 980 / S$

但し，Sは，プランジャーの断面棈 $\left(\mathrm{cm}^{2}\right) 、 980$ は， 重力加速度 $\left(\mathrm{cm} / \mathrm{s}^{2}\right)$ である。

感覚評価：バネルは，本学教職員および食物学科学生 の中から 7 名を選んで構成した，評価項目は，硬さ，付 着性，〈ずれやすさ，ざらつき，水気の 5 項目を選定し た。パネルは，予備実験と討論を繰り返し，Table 1 に 示したように，それそれ愐目の意味付けを行った。評 価は，1 試料ずつ比対照採点法で行い，10\%の EW

Table 1 Sensory texture attributes of sponge cakes defined by texture profile panel

\begin{tabular}{ll}
\hline Hardness & $\begin{array}{l}\text { : Force required to compress a } \\
\text { sample between teeth. }\end{array}$ \\
Adhesiveness & $\begin{array}{l}\text { The perceived degree of adher- } \\
\text { ing to teeth during chewing. }\end{array}$ \\
Crumbliness & $\begin{array}{l}\text { Amount of deformation before } \\
\text { rupture, compressing between }\end{array}$ \\
& teeth. \\
Mealiness & Amount of hard/dry particles \\
& left in mouth during mastica- \\
& tion. \\
Moisture & $:$ Overall impression of mois- \\
& ture content of a sample.
\end{tabular}

調製したケーキを標準試料とした。各項目とも肯定側を 5 点, 否定侧を 1 点とし，標準試料のものを 3 点とした ときの相対的評価を求めた。なお，試料の大きさは機器 測定の場合と同様， $2 \times 2 \times 2 \mathrm{~cm}$ であった。

6. テータの処理法

機器測定および感覚評価から得られたデータは，因子 分析法 ${ }^{12)}$ を用いて統計的に処理した。

\section{結果および考察}

\section{1. タンパク質湜度の変化によるバッターおよびケー キの性状変化}

Fig. 2 は，バッターの空気含量におよばすタンパク 質濃度の影響を示したものである。タンパク質濃度が高 くなるにつれて，EW，EA，SPI の空気含量は減少する 傾向か観察され，各濃度において，EW，EA，よりも SPI の方か低い值を示した。乙の現象は，5\%以上の謈 度で顕著に現われ，特に，12.5\% 以上の濃度では，SPI の空気含量が急激に低下する傾向が観察された。

ハッッターの粘度におよぼすタンパク質濃度の影䉕を示 したのが Fig. 3 である.タンパク質濃度が高まるにつ れて，EW，EA，SPI の粘度は，増加する傾向が観察さ れ，その傾向は EW，EA に比べて SPI の方が顥著で あった. 5\% 以上の濃度において, SPI は高い值を示し, その増加度合いは，12.5\% 以上で特に著しかった. Fig. 2 とと屯に，12.5\%以上における SPI の著しい変化は， 高濃度の SPI におりるゲル化傾向が影㬐しているすの と思われる，すなわち，EW，EA に比べて SPI は濃度 の増大に伴うゲル化傾向が明らかに高く，こ扎は SPI の分子量が EW，EA のそれらに比べて大きいととに起 因していると考えられる。

Fig. 4 には，ケーキの気孔率におよぼすタンパク質 濃度の影響を示した。図からわかるように，SPI のケ 一キ気孔率は，タンパク質濃度によって EW，EA の場 合と異なる傾向を示した。すなわち，SPI ではタンパ ク質濃度の增加につれて，気孔率が一方的に娍少するの に対し，EW と EA では7.5\%をピータにして増加か

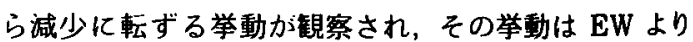
も EA の方が顕著であった。

EW と EA のケーキ気孔率が, $7.5 \%$ で最大值を示 す挙動について明確に説明する資料はまだ充分ではない が，いずれにせよ，擋拌によるバッター中の気泡の状隼 およびそれを焼成した場合のバッター中の高分子成分に よって形成される骨格の強度および形成状態等が，本実 験の条件下においては，7.5\% の場合が最す良いバラン 


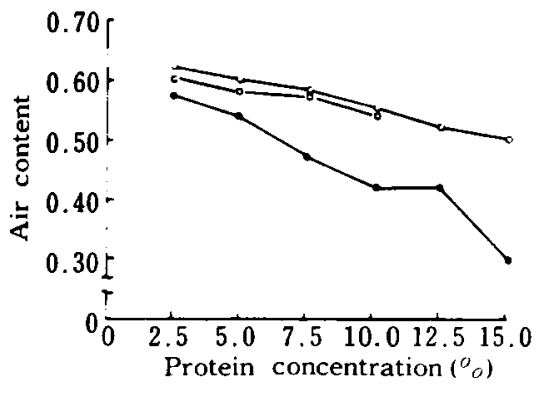

Fig. 2 Effect of protein concentration on air content of batter

$\square$ : Egg white, $\bigcirc:$ Egg albumin,

: Soy protein isolate

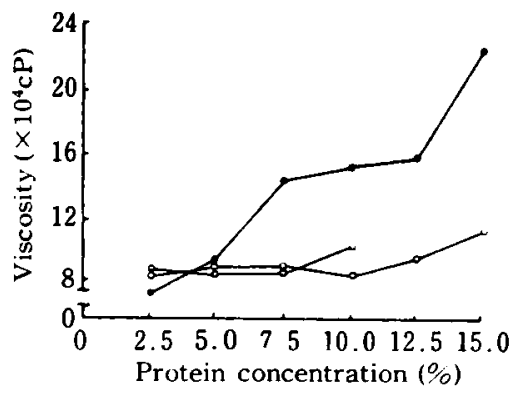

Fig. 3 Effect of protein concentration on viscosity of batter

$\square$ : Egg white, $O$ : Egg albumin,

: Soy protein isolate

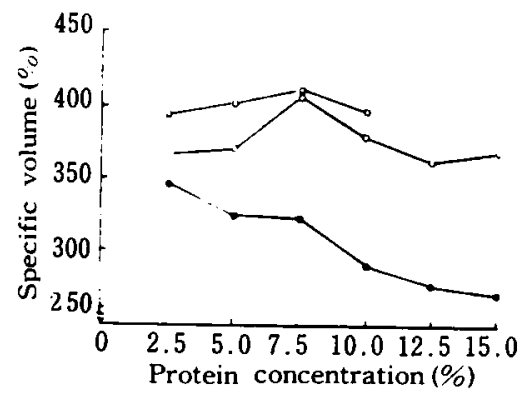

Fig. 4 Effect of protein concentration on specific volume of cakes

$\square$ : Egg white, $\bigcirc$ : Egg albumin,

: Soy protein isolate

スを有していたためではないかと推定される，山上らは， 気泡か加熱によって膨張する力と気泡壁の強度との適度 な組合わせが，良質のケーキを調製するための必要条件 であり，またその強度は気泡壁を形成する成分によって 大きな影篔を受けることを指摘している ${ }^{13) 14)}$ 本実験の
結果で $\mathrm{EW}$ と EA のタンバク質濃度 $2.5 \%$ と\%のケ 一キ気孔率か，7.5\%のそ扎に比べて低いのは，EW と EA のタンパク質濃度が低いためにケーキの等格形成か 弱くなり，これか気孔率の低下をむたらしているものと 推察される．実際に焼成後の“か未おち”の晛象か観察 された。一方，7.5名以上のタンバク質濃度では，かま おちの睍象か起てらない程度の気泡壁の強度を有するか， タンパク質濃度の增加によってバッター中の空気含量か 減少するために，それに伴ってヶーキの気孔率も減少す ることが推察された。実際のケ一未製造の現場において も，各原料を混合した後の EW の実質的タンパク質漉 度は，約 $7.5 \%$ 付近にあるすのと推定され，この点でケ 一キの気孔率か最大になるという今回の実験結果は，経 験的に割り出した条件の妥当性を裹付けるすのとして興 味深い。しかし，SPI の場合，EW および EA の場合 と同じ傾向を示さないのは，バッターの空気含量がタン パク質浱度の増加とともに顕著に減少するためと思われ る. 特に，7.5\% 以上の濃度では気孔率が急激に減少す る傾向か観察された。これは，既に指摘した通り，タン パク質溶液のゲル化傾向によって，ケーキの膨化か著し く抑えら机ることに起因していると考えられる。

2. ケーキの感筧評価と機器測定值との関係

機器測定値間, 感覚評価間, および感覚評価と機器測 定值間の相関保数を Table 2 に示した。 ての表から， 次のことが観察された。すなわち，“疑集性”（No.2） とそれ以外の測定項目之の間の相関係数および “付着性” （No. 6）とそれ以外の測定項目との間の相関㐿数か，

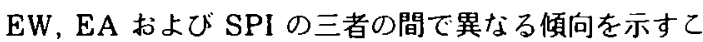
とである. EW の場合，全ての相関係数は正負の 0.9 以上の値を示したか，SPI の場合は “付着性”（No.6） との間の相関係数が, -0.3 之著しく低い值を示した点 を除いては $\mathrm{EW}$ 之同様な傾向であった。 それに対して， EA の場合は全ての感覚評価項目において，正負の 0.9 以上の值を示したものはなかった。 また，“付着性”（No， 6) 之全ての機器測定項目との相関係数では，EW の場 合いずれも負の 0.9 以上の値を示した. EA の場合も $\mathrm{EW}$ 之同様な傾向が認められたが，機器測定項目の“凝集性” （No. 2）との相関係数だけは， +0.5 と低い値を示した。 それに対して,SPI の場合, 全ての機器測定項目にお いて，正負の 0.9 以上の値を示したものはなかった。

次に, Table 2 に示した相関行列を基にして因子分 析を行なった結果，EW，EA，SPI ともに第I因子と第 II 因子で累積寄与率が $98 \%$ 以上を示すてとか認められ たので，これら 2 つ因子の寄与率および因子負荷量に 
Table 2 Correlation matrix of instrumental and sensory attributes

\begin{tabular}{|c|c|c|c|c|c|c|c|c|c|}
\hline \multicolumn{10}{|c|}{ EW" } \\
\hline & 1 & 2 & 3 & 4 & 5 & 6 & 7 & 8 & 9 \\
\hline $1^{2)}$ & 1.000 & & & & & & & & \\
\hline 2 & 0.959 & 1.000 & & & & & & & \\
\hline 3 & 0.988 & 0.990 & 1.000 & & & & & & \\
\hline 4 & 0.943 & 0.992 & 0.981 & 1.000 & & & & & \\
\hline 5 & 0.986 & 0.985 & 0.997 & 0.984 & 1.000 & & & & \\
\hline 6 & -0.956 & -0.990 & -0.986 & -0.999 & -0.991 & 1.000 & & & \\
\hline 7 & -0.934 & -0.983 & -0.973 & -0.999 & -0.980 & 0.998 & 1.000 & & \\
\hline 8 & 0.957 & 0.997 & 0.989 & 0.998 & 0.989 & -0.998 & -0.994 & 1.000 & \\
\hline 9 & -0.949 & -0.989 & -0.983 & -0.999 & -0.988 & 1.000 & 0.999 & -0.998 & 1.000 \\
\hline \multicolumn{10}{|c|}{$\mathrm{EA}^{11}$} \\
\hline & 1 & 2 & 3 & 4 & 5 & 6 & 7 & 8 & 9 \\
\hline 1 & 1.000 & & & & & & & & \\
\hline 2 & -0.681 & 1.000 & & & & & & & \\
\hline 3 & 0.986 & -0.556 & 1.000 & & & & & & \\
\hline 4 & 0.999 & -0.693 & 0.979 & 1.000 & & & & & \\
\hline 5 & 0.990 & -0.570 & 0.997 & 0.987 & 1.000 & & & & \\
\hline 6 & -0.974 & 0.555 & -0.974 & -0.978 & -0.989 & 1.000 & & & \\
\hline 7 & -0.981 & 0.690 & -0.952 & -0.989 & -0.971 & 0.984 & 1.000 & & \\
\hline 8 & 0.966 & -0.502 & 0.978 & 0.968 & 0.989 & -0.998 & -0.969 & 1.000 & \\
\hline 9 & -0.997 & 0.637 & -0.988 & -0.997 & -0.996 & 0.989 & 0.988 & -0.984 & 1.000 \\
\hline \multicolumn{10}{|c|}{ SPI $^{11}$} \\
\hline & 1 & 2 & 3 & 4 & 5 & 6 & 7 & 8 & 9 \\
\hline 1 & 1.000 & & & & & & & & \\
\hline 1 & -0.985 & 1.000 & & & & & & & \\
\hline 3 & 0.993 & -0.990 & 1.000 & & & & & & \\
\hline 4 & 0.980 & -0.990 & 0.997 & 1.000 & & & & & \\
\hline 5 & 0.958 & -0.970 & 0.986 & 0.995 & 1.000 & & & & \\
\hline 6 & 0.173 & -0.314 & 0.176 & 0.207 & 0.160 & 1.000 & & & \\
\hline 7 & -0.973 & 0.985 & -0.993 & -0.999 & -0.997 & -0.202 & 1.000 & & \\
\hline 8 & 0.905 & -0.958 & 0.944 & 0.967 & 0.971 & 0.365 & -0.972 & 1.000 & \\
\hline 9 & -0.988 & 0.986 & -0.999 & -0.998 & -0.991 & -0.159 & 0.996 & -0.949 & 1.000 \\
\hline
\end{tabular}

" EW: Egg white, EA: Egg albumin, SPI: Soy protein isolate

2) 1: Instrumental "Hardness"

2: Instrumental "Cohesiveness"

3: Instrumental "Gumminess"

4: Instrumental "Breaking strength"

5: Sensory "Hardness"

6: Sensory "Adhesiveness"

7: Sensory "Crumbliness"

8: Sensory "Mealiness"

9: Sensory "Moisture" 
Table 3 Results of factor analysis for instrumental and sensory attributes

\begin{tabular}{|c|c|c|c|c|c|c|}
\hline & \multicolumn{2}{|c|}{$(\mathrm{EW})^{1)}$} & \multicolumn{2}{|c|}{ (EA) } & \multicolumn{2}{|c|}{ (SPI) } \\
\hline & $\mathrm{I}^{21}$ & II & I & II & I & II \\
\hline $1^{3)}$ & $-0.970^{41}$ & 0.240 & 0.898 & -0.434 & 0.980 & -0.081 \\
\hline 2 & -0.994 & -0.017 & -0.296 & 0.955 & -0.995 & -0.063 \\
\hline 3 & -0.995 & 0.100 & 0.948 & -0.289 & 0.995 & -0.078 \\
\hline 4 & -0.995 & -0.094 & 0.893 & -0.449 & 0.999 & -0.045 \\
\hline 5 & -0.996 & 0.078 & 0.952 & -0.301 & 0.990 & -0.089 \\
\hline 6 & 0.998 & 0.056 & -0.954 & 0.285 & 0.251 & 0.967 \\
\hline 7 & 0.992 & 0.122 & -0.855 & 0.449 & -0.998 & 0.049 \\
\hline 8 & -0.998 & -0.047 & 0.972 & -0.224 & 0.971 & 0.131 \\
\hline \multirow[t]{2}{*}{9} & 0.997 & 0.077 & -0.925 & 0.380 & -0.995 & 0.095 \\
\hline & $98.696^{51}$ & 1.296 & $92.1 \%$ & $7.2 \%$ & $87.8 \%$ & $11.0 \%$ \\
\hline
\end{tabular}

1) EW: Egg white, EA: Egg albumin, SPI: Soy protein isolate

2) Number of Factors

3) Instrumental and Sensory attributes (1: Instrumental "Hardness "; 2: Instrumental "Cohesiveness"; 3: Instrumental "Gumminess"; 4: Instrumental "Breaking strength"; 5: Sensory "Hardness"; 6: Sensory "Adhesiveness"; 7: Sensory "Crumbliiness"; 8: Sensory "Mealiness"; 9: Sensory "Moisture".

4) Factor loadings

5) Variance explained

ついて検討した（Table 3).EW では，全ての測定項 目が第I因子に高い因子負荷量を示したのに対して， EA と SPIでは第口因子に0.9 以上の因子負荷量を示 す測定項目が観察された，すなわち，EAでは機器測 定項目の“集性”が, SPIでは感覚評価項目の“付 着性”が、それぞれ第正因子に大きく寄与していた。こ れらの結果は，EW，EA および SPI で調製されるケー キのテクスチャーの差異とよく一致することが見出され て興味深い。

テクスチャー・プロファイルによると，EAのケーキ は EWのそれに比へて啮み切りにくく，また，くずれ にくいスポンジ状を呈し，特にタンパク質濃度の増加 によって，ての傾向は顕著に観察された。 また，SPIの ケーキはスポンジ状というよりは粒子の集合体としての 生格が強く，従って EW のケーキに比へて弾力性に之 しく、くずれやすい傾向を示し，歯につきやすくなる特 效を有するすのであった。 そして，その特徴はタンパク 質浱度の增加につれて，明らかに現われた。

以上のととから，EW で調製したケーキのテクスチ ヤーは, 愐目間の関係が一次元的であることから，比較 的単純な系として感覚されるのに対し，EAの場合は機 器测定項目の “凝集性”が, SPI の場合, 感覚評価項目 の“付着性”が，それぞれ他の項目と独立に変動するこ
とから，項目間の関係が二次元的で複合的な系として感 覚される. 同時に，これら独立して变動する項目か，そ れぞれのケーキの感喾的特徵と特佁く関連しているて とが注目された。いずれにせよ，EW，EA および SPI のタンパク質を用いた場合では，出来上がるスポンジケ 一キの性状が，それぞれ基本的に異なることは事実であ る.てのテクスチャ一の本質的な差異が，さらに広範囲 な条件を与えることによって、よ゙のように変化するかに ついて実験を継続中である.

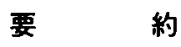

卵白 (EW)，卵アルブミン（EA）および大豆分離タ ンパク質（SPI）の各タンパク質浱度を変化させるとと によって、バッターの空気含量, 粘度およびスポンジケ 一キの気孔率におよぼす影響を調へた。また，ケーキの 感覚評価之機器測定値との関係についても検討した。 そ の結果の概要は次のとおりである.

(1) EW，EAおよび SPI ともに，それらのタンパク 質濃度の增加に伴い，バッターの空気含量は減少する傾 向を，粘度は增加する傾向をそれぞれ示した．てれらの 傾向が EW，EA よりも SPI の方で顕著に観察された のは, タンパク質浱度が $5 \%$ 以上であった。

(2) ケーキの気孔率では，EW，EA とSPIで異なる 
傾问を示した。すなわち、タンパク質の濃度が增加する につれて，SPIの気孔率は一方的に減少するのに対し て，EW および EA の場合は濃度 7.5\%をピークにし て增加から減少に転ずる傾向が観察された。

(3) ケーキの感覚評価上機器测定值上の関係を因子分 析の結果から考察すると，EWで調製したケーキのテ クスチャーは，感覚評価項目之機器測定項目の属性間の 関係が一次元的て，比較的単純な系として感覚されるの に対して，EA とSPI の場合は，属性間の関俰か二次 元的て複合的な系として感覚されることが推察された。

\section{文献}

1) Johnson, T.M. and ZABik, M.E.: J. Food Sci., 46, 1226 (1981).

2) Johnson, T.M. and ZABIK, M.E. : J. Food Sci., 46, 1231 (1981).

3）越智知子.吉川誠次：家政誌，20，151 (1969).

4) Kissell, L.T. and YamazaKI, W.T. : Cereal Chem., 56, 324 (1979).
5）渡辺長男・跉木繁男・岩尾裕之・小原哲二郎螎： 製菒事典，(朝倉書店，東京）p. 335 (1981).

6）藤井淑子 - 島田淳子：家政誌, 34, 616 (1983).

7) Mizukoshi, M., Maeda, H. and Amano, H. : Cereal Chem., 57, 352 (1980).

8) Paton, D., Larcque, G.H. and Holme, J. : Cereal Chem., 58, 527 (1981).

9) Gaines, C.S. and Donelson, J.R. : Cereal Chem., 59, 237 (1982).

10）青木 宏・白瀬好子・加藤潤子・渡辺婎二：日食 工訫, 33， 171 (1986).

11) SzczesniaK, A.S., BRandT, M.A. and Friedman, H.H.: J. Food Sci., 28, 397 (1963).

12）奥野忠一・早米 均・芳賀敏郎. 古沢 正 : 多変 量解析法，（日科技運，東京）p. 323 (1979).

13）山上ユリ子・阿部和代子：松山東雲短大紀要， 5, 137 (1973).

14）山上ユリ子・阿部和代子：松山東雲短大紀要，6, 63 (1974).

(昭和 61 年 8 月 11 日受理)

\section{新刊紹 介}

Quality Control in the Food Industry, Volume 2 Second Edition

HERSCHDOERFER, S. M. 編

本書は多種多様な食品の品質に関して述べた全 4 巻の うちの第 2 巻であり，本巻では水の問題とともに，以下 の 4 種の食品群に分けて, 記されている.

1. Water and Wastewater

2. Dairy Products

3. Meat and Meat Products

4. Fish and Fish Products

5. Edible Oils and Fats

本書は品質に関連する様々な因子，それらの湘定方法， および，それらの制御方法について幅広く述べたもので あり，食品工業にたずさわる人々にとって好著である.

$16 \times 23.5 \mathrm{~cm}, 522$ ベージ, 60 ドル, 1986 年

Academic Press Inc.

Harcourt Brace Jovanovich, Publishers 